\title{
OBITUARY
}

\section{Robert Gibson}

Robert Edward Gibson, Emeritus Professor of Engineering Science at King's College London, died in Worthing, Sussex, England, on 23 December 2008.

Bob, as he was widely known, was born on 12 May 1926 in Felpham, Sussex. He attended Emanuel School, then spent one year at Battersea Polytechnic before transferring to Imperial College to study civil engineering. He was 19 years old when he completed his BSc in engineering. After brief spells at RAE Farnborough and in the Chief Scientific Advisor's Division at the Ministry of Works, he returned to Imperial College to work for a $\mathrm{PhD}$. He was supervised by Profesor Alec Skempton and, after completing his doctorate, remained for a further three years at Imperial College before moving to the Building Research Station in 1953. By 1956 he was back at Imperial, first as a lecturer, then as a Reader, and he moved in 1965 to Kings College London, where he took up a Chair in Engineering Science in 1967, a year after he had received a DSc. He took on various consulting projects parallel with his academic research, and became a Principal at Golder Associates, involved in a variety of projects in North America and the UK. His combination of academic and practical strengths was recognised in the award of an Industrial Fellowship at Wolfson College, Oxford from 1983-1985.

His lasting contributions to geotechnics have been largely due to his passion for mathematics and his ability to develop analytical formulations that could be applied to real engineering problems. He was one of the few researchers whose name is linked to a particular soil model, so that geotechnical engineers across the world recognise a Gibson soil as one in which the stiffness increases linearly with depth. Before this pioneering work was published in the 1960s, the analytical solutions used for foundation design assumed that the stiffness was constant with depth, an assumption that, generally, was far from realistic. In his other major contribution to civil engineering design, he presented an analytical solution to the consolidation behaviour of very soft soils, allowing the inclusion of self-weight as a consolidating force, without the previous constraint that overall strains were small. As construction took place on more difficult ground, and as land reclamation increased, this work became increasingly important, and it continues to be the basis of many current design projects.

In the early days at the Building Research Station, he worked with John McNamee, a mathematician, and this association helped to develop Bob's mathematical insight. They tackled a number of problems of seepage, consolidation and deformation that had previously seemed intractable. A collaboration with W. G. Bickley led to a book on the use of vectors and tensors. He had a long-established friendship and collaboration with Robert (Bob) Schiffman, at the University of Colorado, where Schiffman was Professor of Civil Engineering and Gibson held the position of Adjunct Professor. Schiffman was a pioneer in computer applications, and, together with his students, brought numerical capabilities to their joint research, thus extending the application, especially, of Gibson's work on finite strain consolidation.

Bob's contributions have been in the application of elastic,

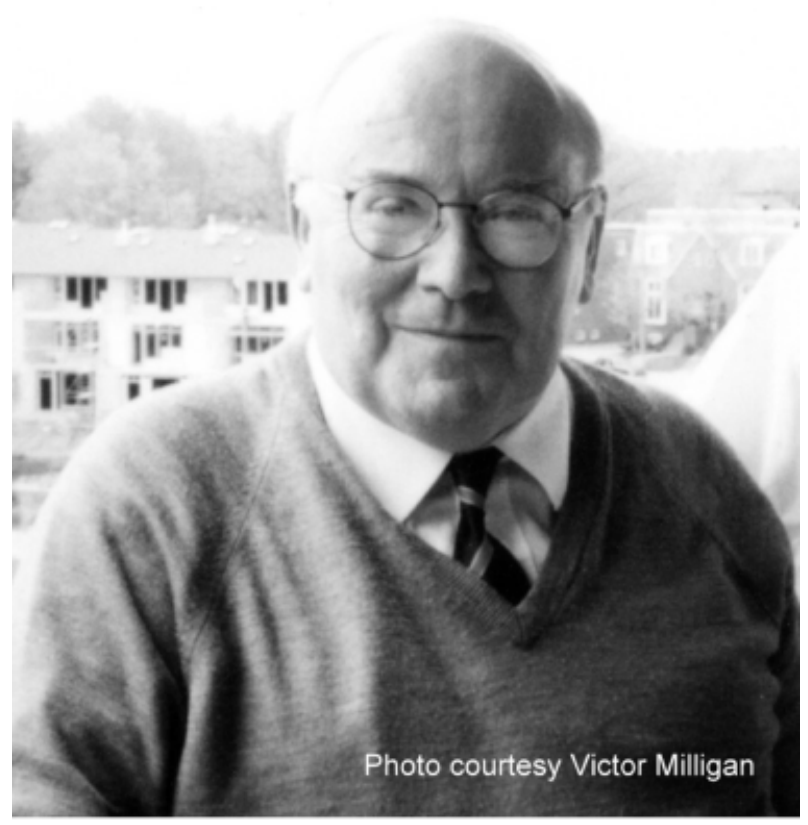

Robert Gibson, 1926-2008

visco-elastic and plastic models to the description of the time-dependent behaviour of soils encompassing primary and secondary consolidation. His ability to solve the complicated equations involved was crucial, but his success was due to his engineering sense and a strong feeling for the way in which soil would behave, as well as in his mathematics. He defined real soil behaviour so that it could be tackled mathematically, thus allowing improved predictions to be made, both for the design of projects such as earth dams, and in the interpretation of new instruments such as the pressuremeter. He was particularly interested in pore pressure. On the practical side, he studied the influence of the boundary drainage on triaxial test results, and the timelags, due to system flexibility, in measured pore pressures in standpipes and in triaxial tests. He used theoretical analyses to show that a coupled consolidation model, rather than Terzaghi's approach, was necessary to predict the rise in pore pressure in the so-called Cryer problem.

His philosophy was spelled out in a letter written in 1997. He wrote 'My friend, Professor Balasubramaniam, has correctly pointed out the tension that has developed, and continues to develop, between 'Theoretical Soil Mechanics' and 'Practical Soil Mechanics'. This I have predicted over the last 25 years. For those who aspire to the highest levels of Consulting Engineering and who wish to be trained to discharge their duties in the highest echelons: they would be well advised to dig deep in to the pool of theory, and read carefully those accounts of failures, so that their perceptions may be sharpened. The rest is up to them!'

His combined mathematical and practical approach made 


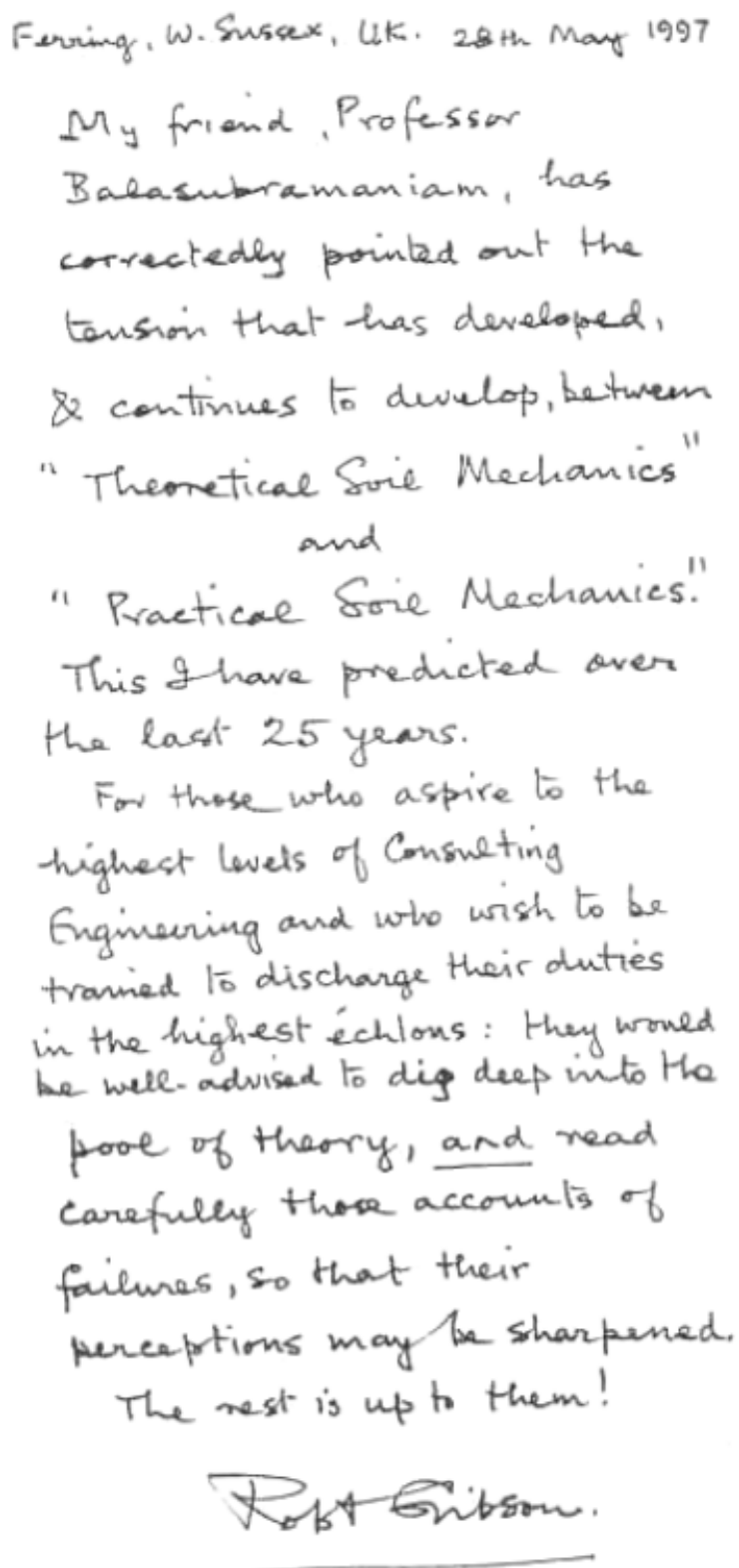

him a very effective consultant. He was part of a collaboration between NGI and Kings College on hydraulic fracturing in permeability measurements, a situation that had arisen in the Dead Sea. He was involved from the early days when Golder Hoek set up an office in Maidenhead, England, where he later became Chairman of Golder UK. His projects for Golder included a soil-structure interaction analysis to define remedial measures for settlement of a section of the Elan Valley Aqueduct, founded on soft clay and supplying water to Birmingham and also an involvement in the investigation for the UK's proposed nuclear waste repository. He contributed to the development of offshore artificial sand islands: huge, impermeable bags filled with sand and water, with the pore water pressure reduced by pumping to increase the effective stress and give strength to the sand. During prototype tests in Christchurch Bay, he carried out on-site calculations that allowed him to provide reassurance that the measured pore pressures were consistent with a successful deployment.

Throughout his career, Bob worked with a large number of researchers and consultants, and many of his collaborators have recorded his generosity, his unstinting willingness to help and their debts to him. One colleague has remembered that everything always looked so simple and straightforward when Bob summarised it, and another recognised his ability effortlessly to educate those he worked with through his infectious enthusiasm, which led to long technical discussions. Another, temporarily trapped in a partly collapsed clay inspection pit, remembers Bob's concern, and also his enquiry, after some time had elapsed, about whether he was experiencing creep forces in addition to those that he felt initially! He was inspirational to his students, remaining in touch with many of them until well after his retirement. Recollections span both theoretical and practical situations: a shared enjoyment of tackling the behaviour of a visco-elastic body in terms of effective stress; or Bob remaining philosophically calm and smiling when confronted with a flooded laboratory.

Bob was highly esteemed in the geotechnical community, and was twice editor of Geotechnique, a unique distinction. One of the panel members under his chairmanship remembers being particularly impressed by his leadership of such a varied group of minds. He was the Rankine lecturer in 1974, and presented a paper entitled 'The analytical method in soil mechanics'. He won various prizes for his papers and his work, including awards by the British Geotechnical Society and the John Booker Medal, and he was elected a Fellow of the Fellowship (now Royal Academy) of Engineering in 1984.

He had a strong sense of enthusiasm for his work and the geotechnical community, a great love for life, music and the company of friends, often accompanied by good wine and good food. Tributes include repeated descriptions of him as 'an intellectual giant', 'a true gentleman', 'an inspiration', 'a most helpful and friendly colleague', 'one of the greats in soil mechanics', and, most frequently of all, that he was a very kind man. He died on 23 December 2008, and leaves a daughter, son and grandchildren.

\section{ACKNOWLEDGEMENTS}

Many people have contributed to this obituary, and I am very grateful to them all. I would particularly like to acknowledge help from A. Balasubramaniam (Bala), Ken Been, John Burland, John Greenwood, Guy Houlsby, Kwan Yee Lo, Caesar Merrifield, Victor Milligan, Donald Moy, Derek Petley, Patrick Selvadurai, Dawn Shuttle, Roger Thompson and Arnold Verruijt.

Gilliane Sills

\section{PUBLISHED WORK: SELECTION}

Brinch Hansen J. \& Gibson, R. E. (1949). Undrained shear strengths of anisotropically consolidated clays. Géotechnique 1, No. 3, 189-204.

Gibson, R. E. (1951). An investigation of the fundamental shear strength characteristics of clays. $\mathrm{PhD}$ thesis, University of London.

Gibson, R. E. (1953). Experimental determination of true cohesion and true angle of friction in clays. Proc. 3rd Int. Conf. Soil Mech. Found Engng, Zurich 1, 126.

Skempton, A. W., Yassin, A. A. \& Gibson, R. E. (1953). Théorie de la force portante des pieux.dans le sable. Annales de l'Institut Technique du Batiment et des Travaux Publics, No. 63-64.

Gibson R. E. \& Lumb P. (1953). Numerical solution of some problems in the consolidation of clay. Proc. ICE 2, No. 2, 182 198.

Gibson, R. E., Lumb, P., Ross, A. D., Severn, R. T. \& Scott, R. F. (1954). Numerical solution of some problems in the consolidation of clay: correspondence. Proc. ICE 3, No. 1, 87-98.

Gibson, R. E. \& Henkel, D. J. (1954). Influence of duration of tests at constant rate of strain on measured 'drained' strength. Géotechnique 4, No. 1, 6-15.

Cooling, L. F. \& Gibson, R. E. (1955). Settlement studies on structures in England. Conference on Correlation between Cal- 
culated and Observed Stresses and Displacements in Structures. London: Institution of Civil Engineers.

Ward, W. H., Penman, A. \& Gibson, R. E. (1955) Stability of a bank on a thin peat layer, session 5/2. Géotechnique 5, No. 2, $154-163$

Gibson, R. E. \& McNamee, J. (1957). The consolidation settlement of a load uniformly distributed over a rectangular area. Proc. 4th Int. Conf. Soil Mech. Found. Engng 1, 297-299.

Drucker, D. C., Gibson, R. E. \& Henkel, D. J. (1957). Soil mechanics and work hardening theories of plasticity. Trans. ASCE 122, 338-346.

Gibson, R. E. (1958). A heat conduction problem involving a specified moving boundary. Q. Appl. Math 16, No. 4,426-430.

Gibson, R. E. (1958). The progress of consolidation in a clay layer increasing in thickness with time. Géotechnique 8, No. 4,171182

Gibson, R. E. (1960). A one dimensional consolidation problem with a moving boundary. Q. Appl. Math 18, No. 2, 123-129.

McNamee, J. \& Gibson, R. E. (1960). Displacement functions and linear transforms applied to diffusion through porous elastic media. Q. J. Mech. Appl. Math. 13, No. 1, 98-111.

Gibson, R. E. (1960). A linear heat problem with a moving interface. Zeitschrift für Angewandte Mathematik und Physik (ZAMP) 11, No. 3, 198-206.

McNamee, J. \& Gibson, R. E. (1960). Plane strain and axially symmetric problems of the consolidation of a semi-infinite clay stratum. Q. J. Mech. Appl. Math. 13, No. 2, 210-227.

Gibson, R. E. \& Marsland, A. (1960). Pore-water pressure observations in a saturated alluvial deposit beneath a loaded oil tank. Proceedings of BGS Conference on Pore Pressure and Suction in Soils, pp. 112-118.

Gibson, R. E. \& Anderson, W. F. (1961). In situ measurement of soil properties with the pressuremeter. Civil Engng Public Works Rev. 56, 615-618.

Gibson, R. E. \& Lo, K. Y. (1961). A theory of consolidation for soils exhibiting secondary compression. Oslo: Norwegian Geotechnical Institute. Publication No. 41.

Gibson, R. E. \& Morgenstern, N. (1962). A note on the stability of cuttings in normally consolidated clays. Géotechnique 12, No. 3, 212-216.

Bickley, W. G. \& Gibson, R. E. (1962). Via vector to tensor: an introduction to the concepts and techniques of the vector and tensor calculus. English Universities Press.

Gibson, R. E. \& McNamee, J. (1963). A three-dimensional problem of a consolidation of a semi-infinite clay stratum. Q. J. Mech. Appl. Math., 16, No. 1, 115-127.

Gibson, R. E. (1963). An analysis of system flexibility and its effect on time-lag in pore-water pressure measurements. Géotechnique 13, No. 1, 1-11.

Gibson, R. E., Knight, K. \& Taylor, P. W. (1963). A critical experiment to examine theories of three-dimensional consolidation. Proceedings of European Conference on Soil Mechanics and Foundation Engineering, Vol. 1, pp. 69-76.

Schiffman, R. L. \& Gibson, R. E. (1964). Consolidation of nonhomogeneous clay layers. Proc. ASCE, J. Soil Mech. Found. Div. 90, No. SM5, 1-30.

Bishop, A. W. \& Gibson, R. E. (1964). The influence of the provisions for boundary drainage on strength and consolidation: characteristics of soils measured in the triaxial apparatus. West Conshohocken, PA: American Society for Testing and Materials, pp. 435-451. STP30020S

Gibson, R. E. (1966). A note on the constant head test to measure soil permeability in situ. Géotechnique 16, No. 3, 256-259.

Gibson, R. E. (1967). Some results concerning displacements and stresses in a non-homogeneous elastic half-space. Géotechnique 17, No. 1, 58-67.

Gibson, R. E. (1967). A note on the constant head tests to measure soil permeability in situ: correspondence. Géotechnique 17, No. $1,68-71$

Gibson, R. E., England, G. L. \& Hussey, M. J. L. (1967). The theory of one-dimensional consolidation of saturated clays. Géotechnique 17, No. 3, 261-273.

Gibson, R. E. (1968). Some results concerning displacements and stresses in a non-homogeneous elastic half-space: correspondence. Géotechnique 18, No. 2, 275-276.

Gibson, R. E. \& Shefford, G. C. (1968). The efficiency of horizon- tal drainage layers for accelerating consolidation of clay embankments. Géotechnique 18, No. 3, pp. 327-335.

Zeitlen, J. G., Scott, R. F., Ko, H. Y., Biariz, J. \& Gibson, R. E. (1969). Stress deformation and strength characteristics, including time effects. Defense Technical Information Centre Research Report ADE603230.

Gibson, R. E. \& Sills, G. C. (1969). On the loaded elastic halfspace with a depth varying Poisson's ratio. Zeitschrift für Angewandte Mathematik und Physik (ZAMP), 20, 691-695.

Gibson, R. E. (1969). Some results concerning displacements and stresses in a non-homogeneous elastic half-space: correspondence. Géotechnique 19, No. 1, 160-161.

Gibson, R. E., Schiffman, R. L. \& Pu, S. L. (1970). Plane strain and axially symmetric consolidation of a clay layer on a smooth impervious base. Q. J. Mech. Appl. Math. 23, 505-520.

Gibson, R. E. (1970). An extension to the theory of the constant head in situ permeability test. Géotechnique 20, No. 2, 193197.

Gibson, R. E., Brown, P. T. \& Andrews, K. R. F. (1971). Some results concerning displacements in a non-homogeneous elastic layer. Zeitschrift für Angewandte Mathematik und Physik (ZAMP) 22, 855-864.

Gibson, R. E. \& Sills, G. C. (1971). Some results concerning the plane deformation of a non-homogeneous elastic half-space. Proceedings of Roscoe memorial symposium on stress-strain behaviour of soils, Foulis, pp. 564-572.

Bjerrum, L., Nash, J. K. T. L., Kennard, R. M. \& Gibson, R. E. (1972). Hydraulic fracturing in field permeability testing. Géotechnique 22, No. 2, 319-332.

Brown, P. T. \& Gibson, R. E. (1972). Surface settlement of a deep elastic stratum whose modulus increases linearly with depth. Can. Geotech. J. 9, No. 4, 467-473.

Gibson, R. E. (1972). Discussion of 'Observed and predicted deformations in a large embankment dam during construction by Penman A. D. M., Burland J. B. and Charles, J. A. Proc. ICE 1971, 49, No. 1, pp. 1-21'. Proc. ICE 51, 741-742.

Evans, R. J. \& Gibson, R. E. (1973). Discussion of 'Double sliding free rotating model for granular assemblies by de Josselin de Jong, Géotechnique 1971, 21, No. 2, 155-163, 1973', Géotechnique 23, No. 3, 459-459.

Brown, P. T. \& Gibson, R. E. (1973).Rectangular loads on inhomogeneous elastic soil. J. Soil Mech. Found. Div., ASCE 99, No. 10, 917-920.

Awojobi, A. O. and Gibson, R, E. (1973). Plane strain and axially symmetric problems of a linearly homogeneous elastic half space. Q. J. Mech. Appl. Math. 26, 285-302.

Burland, J. B., Sills, G. C. \& Gibson, R. E. (1973). A field and theoretical study of the influence of non-homogeneity on settlement. Proc. 8th Conf. Int. Soc. Soil Mech. Found. Engng, Moscow, 39-46.

Gibson, R. E. (1974). The analytical method in soil mechanics: 14th Rankine lecture. Géotechnique 24, No. 2, 115-140.

Gibson, R. E. \& Kalsi, G. S. (1974). The surface settlement of a linearly inhomogeneous cross-anisotropic elastic half-space. Zeitschrift für Angewandte Mathematik und Physik (ZAMP) 25, 843-847.

Brown, P. T. \& Gibson, R. E. (1974). Surface settlement of a deep elastic stratum whose modulus increases linearly with depth: erratum. Can. Geotech. J. 11, No. 1, 222-222.

Gibson, R. E. \& Sills, G. C. (1975). Settlement of a strip load on a non-homogeneous orthotropic incompressible elastic half space. Q. J. Mech. Appl. Math. 28, 233-243.

Gibson, R. E. (1977). Some results concerning displacements and stresses in a non-homogeneous elastic half-space: discussion. Géotechnique 27, No. 2, 253-254.

Gibson, R. E. \& Dowse, B. E. W. (1981). The influence of geotechnical engineering on the evolution of offshore structures in the North Sea. Can. Geotech. J. 18, 171-178.

Gibson, R. E., Schiffman, R. L. \& Cargill, K. W. (1981). The theory of one-dimensional consolidation of saturated clays II: finite non-linear consolidation of thick homogeneous layers. Can. Geotech. J. 18, No. 2, 280-293.

Gibson, R. E., Schiffman, R. L. \& Cargill, K. W. (1982). The theory of one-dimensional consolidation of saturated clays II: finite non-linear consolidation of thick homogeneous layers: reply. Can. Geotech. J. 19, 116-116. 
Schiffman, R. L., Pane, V. \& Gibson, R. E. (1984). The theory of one-dimensional consolidation of saturated clays, IV: an overview of nonlinear finite strain sedimentation and consolidation. Sedimentation and consolidation models (eds R. N. Yong and F. C. Townsend), pp. 1-29. Reston, Virginia: American Society of Civil Engineers.

Gibson, R. E. (1984). Working with Skempton. Selected papers on soil mechanics. London: Thomas Telford.

Gibson, R. E., Goldsworthy, M. H. \& Chandler, A. M. (1985). Differential evapo-transpiration from a clay surface and its influence on equilibrium porewater pressure. Géotechnique 35, No. 2, $181-191$.

Gibson, R. E. (1989). The pore water pressure distribution in a tailings basin during and after construction, with reference to the tailings dam disaster at Stava, near Tesero, 19 July 1985. Technical report for the Trento appeal trial, September 1989. In: A review of the scientific contributions on the Stava valley disaster (eastern Italian Alps), 19 July 1985 (ed. G. Tosatti). Special volume of the GNDCI- CNR, 2003, 151-156, 2003, Bologna: Pitagora editrice.

Gibson, R. E. (1986). Centrifugal consolidation testing of soft soil. Defense Technical Information Centre No. ADA172365.

Schiffman, R. L., Vick, S. G. \& Gibson, R. E. (1988). Behavior and properties of hydraulic fills. In Hydraulic Fill Structures ASCE Geotech. Special Pub. (eds D. J. A. Van Zyl \& S. G. Vick) 21, 166-202.

Mitchell, J. K. \& Gibson, R. E. (1989). Obituary Seed, Harry Bolton 1922-1989. Géotechnique 39, No. 3, 571-580.

Gibson, R. E., Gobert, A. \& Schiffman, R. L. (1989). On Cryer's problem with large displacements. Int. J. Numer. Analyt. Methods Geomech. 13, No. 3, 251-262.

Gibson, R. E., Schiffman, R. L. \& Whitman, R. V. (1989). On two definitions of excess pore water pressure. Géotechnique 39, No. 1, 169-171.

Gibson, R. E., Gobert, A. \& Schiffman, R. L. (1990). On Cryer's problem with large displacements and variable permeability. Géotechnique 40, No. 4, 627-631.

Gibson, R. E. \& Sills, G. C. (1990). Consolidation due to under- pumping an accreting layer of sediment. O. J. Mech. Appl. Math. 43, No. 3, 335-346.

Gibson, R. E. (1991). Obituary Golder, Hugh Q. 1911-1990. Géotechnique 41, No 3, 475-477.

Szavits-Nossan, V., Schiffman, R. L. \& Gibson, R. E. (1992). Discussion of 'SOA: large strain consolidation predictions by $\mathrm{F}$. C. Townsend and M. C. McVay. J. Geotech. Engng, 1990, 116, No. 2'. J. Geotech. Engng. 118, 168-168.

Gibson, R. E. (1993). Consolidation of an accreting clay layer: solutions via the wave equation. Predictive soil mechanics Wroth memorial symposium, pp. 293-303.

Schiffman, R. L., McArthur, J. M. \& Gibson, R. E. (1994). The consolidation of a clay layer: hydrogeologic boundary conditions. Proc. ASCE, J. Geotech. Engng Div. 120, 1089-1093.

Potter, L. J., Savvidou, C. \& Gibson, R. E. (1994). Consolidation and pollutant transport associated with slurried mineral waste disposal. Proc. 1st Int. Congress Environmental Geotechnics, 525-530.

Gibson, R. E., Potter, L. J., Savvidou. C. \& Schiffman, R. L. (1995). Some aspects of one-dimensional consolidation and contaminant transport in wastes. Proceedings of international symposium on compression and consolidation of clayey soils (eds H. Yoshikuni and O. Kusakabe), Hiroshima, Vol. 2, pp. 815-845.

de Boer, R., Schiffman. R. L. \& Gibson, R. E. (1996). The origins of the theory of consolidation: the Terzaghi-Fillunger dispute. Géotechnique 46, No. 2, 175-186.

Potter, L. J., Savvidou, C. \& Gibson, R. E. (1997). Consolidation and pollutant transport associated with slurried mineral waste disposal. 14th Int. Conf. Soil Mech. Found. Engng 3.

de Boer ,R., Schiffman, R. L. \& Gibson, R. E. (1997). The origins of the theory of consolidation: the Terzaghi-Fillunger dispute: discussion. Géotechnique 47, No. 4, 893-895.

Potter, L. J., Loroy, J. J. C., Soga, K., Savvidou, C. \& Gibson, R. E. (1997). Mineral waste disposal: numerical and centrifuge modeling. Proc.14th Int. Conf. Soil Mech., 1847-1852.

Gibson, R. E. (1998). Obituary: Robert L. Schiffman 1923-1997. Géotechnique 48, No. 5, 715-718. 